\title{
Catholic Senior High School Students' Attitude toward Morality of Cheating and Academic Cheating Behaviours
}

\author{
Damianus Abun ${ }^{1}$, Theogenia Magallanes ${ }^{2}$, Sylvia Lalaine Foronda ${ }^{3}$, Mary Joy \\ Encarnacion $^{4}$
}

${ }^{1} \mathrm{Ph} . \mathrm{D}$ : Divine Word College of Vigan, and St. Benedict College of Northern Luzon, Philippines. ${ }^{2}$ Ed.D: St. Benedict College of Northern Luzon and Divine Word College of Vigan, Philippines ${ }^{3}$ Ph.D: Divine Word College of Laoag, Philippines

${ }^{4} \mathrm{Ph} . \mathrm{D}$ (candidate): Divine Word College of Vigan, Philippines

\begin{abstract}
The study wanted to determine the relationship between cognitive and affective attitude of students toward the morality of cheating and their academic cheating behaviours in the classroom. In order to carry out the study, theories were proposed related to the concept of human attitude and human behaviour and its relationship, the concept of morality and the attitude of Filipinos toward morality and the concept of morality of cheating. Therefore related literature and studies along those concepts were reviewed. To gather the data, validated questionnaires were used and in order to interpret the data statistical tools were used such as weighted mean and Pearson $r$ or Pearson correlation coefficient was used to determine the correlation between the two variables. The study found that Senior High School students of Divine Word Colleges in Region I have high positive cognitive and affective attitude toward morality of cheating and their negative cognitive and affective attitude were considered low and moderate. In terms of their cheating behaviour, it was found to be low. The study further found a correlation between positive and negative cognitive attitude toward morality of cheating and their cheating behaviour. In relation to their affective attitude, it was found that there is a significant correlation between positive affective attitude toward cheating and academic cheating behaviour and no correlation between negative affective attitude toward the morality of cheating and academic cheating behaviour.
\end{abstract}

Keywords-Cognitive and affective attitude, human attitude, human behaviour, morality, cheating, academic cheating behaviour.

\section{INTRODUCTION}

Common consensus on what is moral and immoral is very important for common perception on the morality of certain behaviour. The purpose of morality or moral norms is for everyone to have a common understanding about what good and bad is or what wrong and right is. These norms are used for standards of behaviours. Behaviours must conform to those standards in order to be morally correct or good. However, compliance does not happen automatically. People's compliance to morality occurs when those standards match with the actual behaviour of those who are supposed to be the role model of society. Non-compliance occurs when there is a discrepancy between the two, between what the community believe to be moral and what they see in real life of those who are supposed to be the model of good moral conduct. There is a deficit or discrepancy. As a result of such deficit, instead of compliance but non-compliance. Consequently, the purpose of morality to change the behaviour fails. It is the same case with the compliance toward the law. People will comply with the law if the law reinforces what people believe to be just or right but people will not comply to the law if the law does not reinforce what people believe to be good, just or unjust. As a result, instead of complying, people will rebel against it and thus, its goal to change behaviour fails (Bilz \& Nadler, 2014).

In relation to the Catholics, the behaviours of people are guided by the teaching of the Catholic Church which is sourced from the Holy Bible. The Bible has given the Ten Commandments and the $8^{\text {th }}$ commandment is about stealing which states, "Thou shalt not steal". Stealing equates with 
cheating and cheating is dishonesty and against academic integrity. Thus, it is a common consensus in Catholic community that cheating is a moral issue and it is considered a dishonesty. It is an issue of immorality because it violates the religious teaching. Thus, cheating is not just a violation of moral values but it is also a violation of religious values or teaching. In the academic setting, cheating is a violation of academic integrity as defined by McCabe (2016). It is a moral code or ethical policy of academia which may include policies on cheating, plagiarism, honesty, trust, diligence, fairness, and respect. Therefore, the students must not cheat during the exam, and respect the opinion and the right of others by acknowledging the authors. But as indicated above that compliance to morality is not guaranteed. Some people may comply and others may not comply because cheating has been tolerated in many instances. The students know that cheating is immoral but if they have seen in reality to be otherwise, then they may not comply and may continue to be cheating. Moral discrepancy weakens the enforcement of moral norms in life and therefore it fails to reform the behaviour of the students.

The current study focuses on the Catholic students' behaviour on cheating because of the fact that these students have been taught with religion and ethics subject. Since the students have studied religion and ethics, thus, it is assumed that they understand the morality of cheating, that cheating is morally wrong. However, such assumption may not be found in reality because students may have been living in the cheating environment. Compliance to the rule of "no cheating" policy may suffer. Logic may not be always applicable to morality. There is always moral discrepancy (Shu, et.al, 2011). Many have recognized that cheating has become common problem in the academe nowadays. But those studies have not pointed out specific group of religion in it. Current study would like to take on the Catholic students' attitude on morality and how it affects their cheating behaviour. The reason why the Catholic students are chosen because of the fact that they are taught about religion and ethics. We would like to see if their attitudes toward morality particularly cheating affects their actual behaviouralon cheating. The study is relied on the theory of Ajzen and Fishbein (1975) and Allport (1968) that attitudes affect the behaviour.

\section{The Objective of the Study}

The study would like to find out the relationship between attitude toward morality of cheating of Catholic Senior High School students and their cheating behaviour. This is to determine how they view cheating in terms of its morality and how such view affects their real cheating behaviour. Consequently, the output of the study can be used to educate students about cheating as a morality issue and probably help the management to establish policies to prevent cheating.

\section{THEORETICAL FRAMEWORK}

On the theoretical framework, I adopted the previous concept that I have discussed in other papers related to the students' attitude toward higher education, toward research, toward corruption, toward environment that were published in other international journals. The ideas on attitude and behaviour are the same as I have presented in the previous papers and so it is not surprising, if a reader found the same idea and presentation in other papers that I have published. The ideas on attitude and behaviour are based on the ideas of Ajzen and Fishebin $(1977,2000)$ and the idea of Allport (1968) and other researches on the relationship between attitude and behaviour. After reading the ideas of Ajzen and Fishbein and Allport and many other researches, I am convinced of the theory of attitude that affects behaviour.

\section{The concept of Human Attitude}

Attitude is an individual's disposition to react to certain object, behaviour, person, institution, event or other discriminable aspect of the individual's world (Ajzen, 1993). Ajzen contended that there can be a lot of definitions of attitude from different theorists, however, there is a common agreement among them that attitude has its evaluative dimension (Bem, 1970, Edwards, 1957, Fishbein \& Ajzen, 1975). In the sense that dimensions of attitude can be measured and evaluated. Ajzen (1993) recognized that though attitude is inaccessible to observations because it is within the person's mind or it is latent but it can be measured through the reaction or responses of the person toward the object of the attitude which may be favourable or unfavourable toward the object, persons, institution, events or situations. There are three categories of responses or reactions and they are cognitive, affective and conative responses (Allport, 1954, Hilgard, 1980, Rosenberg \& Hovland, 1960). These are manifestations of salient or latent attitude which is unobservable (Ajzen, 1993). Cognitive component refers to the beliefs and thoughts about the subject, the object, the person, the institution, the event, etc. It is about the perception and information of the person toward the subject, object or the person. Affective component of attitude is an emotional reaction toward the subject, object or the person. It is how one feels when he/she is confronting the subject, object, the person or the 
institution. It is still a psychological reaction which may be verbal or nonverbal expression of feelings toward the subject, object, the person or the institution. Such reaction may be negative or positive. While conative component of attitude is the effect of the attitudes toward a behavioural intention or how the attitude affects one's behaviour. These may include plans, intentions and commitments to a planned behaviour. These are the three components of attitude and therefore, attitude is a multidimensional construct.

The question can be raised in relation to the origin of attitude: where does it come from? According to Ajzen (1993), a person develops such attitude perhaps as a result of watching television program or may be other kind of exposures or experiences. But Abun (2017) went deeper to answer that question in relation his argument on how to solve environmental problem. According to him, that environmental problem is a result of human behaviour and destructive human behaviour is originated from the culture and thus solving environmental problem is to revisit the culture that have influenced the mind of people toward the environment. He contends that attitude is originated from the culture where the person is raised. His argument was based on the ideas of anthropologists such as Donald (2002), Hofstede as cited by Brown (1995). Donald (2002) argued that culture is playing important role on our brain functioning and even brain structure. She has pointed out that language has the biggest impact on brain structure but that culture influences brain functioning to a great extent as she writes:

The social environment includes many factors that impinge on development, from bonding and competitive stress to the social facilitation of learning. These can affect brain functioning in many ways, but usually they have no direct influence on functional brain architecture. However, symbolizing cultures own a direct path into our brains and affect the way major parts of the executive brain become wired up during development. This is the key idea behind the notion of deep enculturation... This process entails setting up the very complex hierarchies of cognitive demons (automatic programs) that ultimately establish the possibility of new forms of thought. Culture effectively wires up functional subsystems in the brain that would not otherwise exist.

The idea of culture and its effect on brain functioning indicates the power of culture over the formation of the mind and ideas of people about everything around them (Abun,
2017). Donald's view is similar to what Hofstede as cited by Brown (1995) as he argued that culture is the collective programming of the human mind that distinguishes the members of one human group from those of another. Hofstede pointed out clearly that that culture is reflected in how people think, how people view things or attitude. To elaborate the idea of Hofstede, Amstrong (1996) contend that there is a relationship between cultural dimensions and ethical perceptions. In other words, ethical attitude is formed by a particular culture. One perceives certain object, subject, person or institution to be negative or positive, favourable or not favourable because he/she has been taught by the culture of a particular society where he/she is living. What he/she learns from the culture will be his/her ideas about certain subject, object or events, etc. that he/she will encounter.

\section{The View of Human Behaviour}

To understand the root cause of human behaviour, it would be helpful to revisit the idea of William James, a pragmatist, a behavioural psychologist, as cited by Lawler (2006). James is against the idea that all human behaviour is shaped by experience, but it is shaped by the brain or the mind. Though James recognized that humans are ruled by their instincts as other animals do, but what make humans behave the way they do and how they behave the way do is different from animals. James went on to explain that though humans are animals with the most instincts, but they will never react automatically to the instincts, the way inferior animals do because humans have the mind or the reason. It is the role of reason. Reason has to create another impulse to neutralize another impulse.

To complicate further the root cause of human behaviour, Ridley (2011) turns his attention to the nature versus nurture debate to bring the first popular account of the root of human behaviour with this unique question: "what makes us who we are?" This question is related to the main question of why humans behave the way they do and how they behave the way they do. The immediate answer to these questions may point to the very essence of human being that differentiates it from animal which the reason or the mind is. But Nohria, Sandelands and Lawrence (2003), instead of pointing at reason or mind as the source of human behaviour, she pointed out four drives or qualities that shape human behaviour. According to her, these drives or qualities are important to understand why humans behave the way they do. These qualities or drives are conflicting, and they do not work automatically. They force us to make deliberate decisions and choices with certain degree of liberty. According to this argument, drives or qualities that shape our 
human behaviour are first, drives to gain object, bodily and emotional experience, maintaining life and improving one's social status in relation to others. Second, drive to create relations, to belong to a group and create a long terms relationship and caring for others. Third, drive to gain insight including understanding one's self and one's surroundings. Fourth, drives to control and defend. These are the qualities for us to understand why we behave in a certain way. In other words, human behaviour is driven by purposes to be accomplished, not just like other animals.

The later argument brings us to the theory of planned behaviour of Ajzen (1985, 1987, Ajzen \& Madden, 1986). Theory of planned behaviour (TPB) is an extension of theory of reasoned action to explain the relationship between attitudes and behaviour within the human action. Reasoned Action Theory (RAT) argues that reason for action will predict how individual will behave based on their preexisting attitude and behaviour intention. The theory argues that an individual will behave based on the expected outcome the individual expects to achieve as a result of performing such behaviour (Fishbein \& Ajzen, 1975, Ajzen \& Fishbein, 1980). If RAT focuses on the reason, while the central attention of Theory of Planned Behaviour or TPB is the individual's intention to perform a given behaviour. There are three independent determinants of intention. First determinant is the attitude toward the behaviour. At the level, the person who perform certain behaviour must evaluate if the behaviour in question is favourable or not favourable. Second determinant is social factor or subjective norms. At this level, the person who perform the act must evaluate if the society is in favour or not in favour of such act or behaviour. Third is the novel antecedence of intention. This refers to the perceived ease or difficulty of performing the behaviour and it is assumed to reflect past experience on performing the behaviour and anticipated impediments and obstacles in performing the behaviour. It suggests that the more favourable the attitude and subjective norms with respect to a behaviour, and the greater the perceived behavioural control, the stronger should be an individual's intention to perform the behaviour under consideration (Ajzen, 1993).

In short, the theory of planned behaviour argues that the stronger people's intention to perform certain behaviour, or the stronger people's intention to achieve their behavioural goals the more likely they engage in such behaviour. However, Ajzen (1993) cautions us that the degree of success does not depend only on intention but there are circumstances that may prevent us to realize the behaviour in consideration and these may include opportunities and resources such as time, money skills, and other necessary requirement to perform such behaviour. These factors represent the actual control over the behaviour. Beyond that, since TPB is concerned with the perceived behaviour, the particular perceived behaviour may not be carried out due to lack of information about the behaviour, the requirements have changed and when other unpredicted elements have entered into the situation.

\section{The Effect Attitude toward Behaviour}

In psychology, an attitude is defined as a set of emotions, beliefs, and behaviours toward a particular object, person, thing, or event (Banaji \& Heiphetz, 2010). It is a learned tendency to evaluate or perceived things in a certain way and therefore one can have positive or negative evaluation or perception of certain objects, experiences, practices, etc. The evaluation or perception of a person toward certain object or experience is not isolated from experiential exposure. It has been a common understanding and agreement that attitudes are results of experience, upbringing/education and social interactions. Experience or upbringing or education can have powerful influence over attitudes. However, since attitude is not independent from environment or experience, thus it is also accepted that attitudes are dynamics in the sense that it is enduring and the same time it can also be changed (Cherry, 2019).

Most of the early researches on attitude accepted as a given that attitude influenced the behaviour. The background of those studies was influenced by the ideas of the early social psychologists that attitude is a key to understand human behaviour (Thomas \& Znaniecki, 1918, Watson, 1925). This idea was taken for granted for quite some time until the time that later studies proved otherwise. Some investigators challenged the earlier assumption through field studies on the relationship between attitude and behaviour and their studies found that there was no correlation or little correlation between attitude and behaviour. For example, Corey (1937), Freeman \& Ataoev, (1960) as cited by Ajzen (1993) conducted a study on the college's students' attitude at the beginning of the semester and provide multiple opportunities to cheat by allowing them to score their own test. His test found that there was no correlation between students' attitude and their cheating behaviour (Ajzen, 1993, p.74). Even later studies supported the study of Corey (1937). For example, Dean (1958) conducted a study on attitude toward labour unions and participating in labour union meetings, and his study found no correlation. The similar study was also done by Wicker and Pomazal, (1971) on the attitude toward 
participating a subject in social psychology and actual participation in social psychology class. Their studies found no correlation.

The finding of later studies particularly the study of Wicker (1969) seem discouraging the original idea of early social psychologists that attitudes is the key to predict behaviour. The results of those studies have questioned the importance of studying the personal disposition and behaviour. By 1970s most social psychologists accepted the negative verdict of the relation between attitude and behaviour. Instead of studying the relation between attitude and behaviour, they encouraged the study of social context and norms as determinant factor in predicting the behaviour or human action (De Fleur \& Westie, 1958, Deutscher, 1969). However, given those negative result, other social psychologists, particularly Ajzen and Fishebin (1977, 2000,) still maintain that attitude is still key to predict the behaviour (Allport, 1968). Allport (1968) still considered attitude to be "the most distinctive and indispensable concept in contemporary American social Psychology" (p. 59). Other social psychologists who were against the negative finding of early research argued that the inconsistencies are not with the attitude and behaviour itself, but it may happen because of many factors such as response biases, multidimensionality of attitudes, and moderating variables. In terms of response biases, they argue that there is a tendency to give socially desirable responses on attitude and personality inventories and along this point, they recommended the need to use attitude measures that are less subject to systematic biases (Ajzen, 1993). In relation to multidimensionality of attitudes, they pointed out that most attitude measurement technique resulted in a single score representing the respondent's overall positive or negative reaction to the attitude object. According to them, focus on a single dimension did not do justice to the complexity of the attitude construct (Allport, 1935). Single construct is against attitude as multidimensional construct which include cognition, affective and conation component (Rosenberg \& Hovland, 1960). Lastly, the inconsistencies are due to moderating variables. They argued that the degree of attitude behaviour consistency was assumed to be moderated by factors related to the person performing the behaviour such as self-awareness, self-efficacy, self-monitoring, experience, self-confidence, even feeling and lack of information or knowledge. They also pointed out to the situation as moderating variable such as time pressure or circumstances surrounding performance of the behaviour (Ajzen, 1993).

The recent studies conducted by Abun (2017) and Fitzsimmons and Douglas (2005) confirmed the consistency of attitude and behaviour. Abun (2017) measured the relationship between environmental attitude and environmental behaviour and the study found that environmental attitude predicted the environmental behaviour of the students and employees toward the environment. Further, he also conducted a study on the entrepreneurial attitude and future intention to establish a business and the finding also indicated a correlation. The study of Fitzsimmons and Douglas (2005) also found that entrepreneurial attitudes are significant in explaining career decision in the future and their intention to go into business.

\section{The Catholic's Concept of Morality}

The concept of morality of the Catholics may be different from the ordinary and professional concept of morality. Ordinary concept of morality is about prescribed standards that "people endorse for their non-professional and private lives and professional morality is binding obligation to which a profession ought to be committed because of their skills and functions" (Martin, 1981, p. 631). The first is emanated from human condition and the second is emanated from the demand of the profession. While Catholic morality is prescribed moral behaviour for all Catholics which is emanated from the doctrine of the Catholic Church and such doctrines are based on the Holy Bible as the Words of God. In other words, Catholic morality is faith centred behaviour that is consistent with the core beliefs as Catholics. The code of moral conducts that are prescribed by the Catholic Church are a way of how the Catholic Church guides its followers tolive according to their identity as Christians, follower of Christ. The Catholic Church guides its people through its prescribed moral behaviour so that Catholics may become true followers of Christ (O'Neil, \&Black, 2004). It is developed by the acts of Magisterium, by the Pope, by the bishop conference, and by the work of Catholic Theologians. The nature of Catholic morality is deontological, in the sense that Catholic moral behaviour is based on the prescribed moral conduct established by the Church, on how "they should act" in a particular situation or problem. These are norms or moral standards to be followed and these norms are consistent with the creed of the Catholic Church, and it is not based on individual judgment or situation and not based on the consequence of the action (Flew, 1979).Its nature is imperative which means that a Catholic has no other choice except to follow what is written or what is commanded to do in that particular situation. Emmanuel Kant may call it a "duty "or obligation to follow the rules (Waller, 2005). According to Emmanuel Kant, in order to act in a morally right way, people must act from duty (Abbott, 1889). 
Example, when you see sick people on the road side, the rule is that you should help the person and neglecting to do such duty is immoral. Or the rule is that we should protect human life and therefore any act against the right to life is immoral such as abortion. Or Catholic Church prohibits stealing and therefore any Catholic should not steal despite of the consequence of such action. Therefore, Catholic morality is contrasted with the consequentialism (Flew 1979).

The moral teaching of the Catholic Church is often carried out by official statements of doctrine such as papal encyclicals, which is based on the dogmatic pronouncement of ecumenical Councils (Vatican, II), Sacred Scriptures and Sacred Tradition forwarded by the Church Fathers. Beside deontological approach, Catholic morality is also using teleological approach, in the sense that besides using the rules as guide to moral behaviour, the behaviour is also guided by the end or the purpose of the act. How one should act is guided by the ultimate end of the act which is again established by faith (Catholic Encyclopedia, n.d). The good end of the act is an essential consideration in the moral judgment of the act and such end must be in consonance with the faith. Because, after all, moral living is a response to the Word of God. Faith in God translates into a responsibility of moral living (Ratzinger, 2005).Thus, Catholic morality is about life in Christ, as pointed out by John, 10: 10: "I came that they may have life, and have it abundantly". Through the baptism, Christians share the life of Christ and therefore the life of Christians are the life of Christ himself.

Thus, Catholic morality have actual code of conduct as reflected in the Ten Commandments but it does not represent the summit of Catholic morality. It is only the basic requirement and summary of main law to love God and to love your neighbour as yourselves. The minimum requirement of basic Christian living is already reflected in the Ten Commandments. It is a summary of what one ought to do. It is a description of basic freedom from sin as a necessary way or basic principles to live in Christian way or to live in Christ (O'Neil \& Black, 2004). These commandments may be originally from the Old testament but Christ had assured the validity of these commandments in the dialogue of Jesus with the young man who was looking for ways how to gain eternal salvation (Mt.19:16-21). These commandments are concrete summary of the law of love of God and neighbour. Beyond the Ten Commandments which are found in the Scripture, the Catholic morality is guided by the teaching of the authority of the Catholic Church such as Pope, and Bishops Conference.
Though Christian morality seems to be rule-based morality but it never denies the fact that following those should be free. Therefore, freedom is the basic concept of Catholic morality which means that we are given the choice, either to follow those rules or not to follow, based on our reason and freewill. However, each is responsible for his/her choices and thus, we choose our own destiny, is either to live with God or death. Freedom is the gift given by God to human beings compared to other creatures which develop according to their genetic structure, subject to the circumstance of the environment. Christian moral life is marked chiefly by human freedom, their ability to shape their life, either for good or for evil (O'Neil \& Black, 2004). Beside freedom as the basic feature of Catholic morality is objective nature which means that Catholic morality is not based subjective judgment but it is based on moral truth, in the sense that it is always valid at all times and everywhere and applied to all believers everywhere beyond the boundary of the culture. The source of all moral truth is God himself which is pronounced through the authority of the Catholic Church (O'Neil \& Black, 2004). God has chosen to reveal its moral truth to all rational human beings through his/her reason. It is an inner directive that flows from the nature of human beings and directs them to the fullness of life (O'Neil \& Black, 2004, Himma, n.d).It is a natural inclination of the human mind. These laws are written in the mind and are carried out by conscience. It is the conscience that judge specific action to be right or wrong in accordance with the objective law, it is an inner directive toward what is good and we have only one idea to point out the source of such direction is divine providence in the terms of Thomas Aquinas (Murphy, 2019).

\section{Attitude of Filipino Catholic toward Morality}

It is recognized that one of the factors that form human attitude is experience or exposure toward the environment as pointed out by Ajzen (1993). Constant exposure toward the same object or experience can form the concept of the person toward the object or experience. A kid who is in constant exposure with good and bad habit of his/her parents, school and peer group can form his/her perception or attitude toward what is good and bad. Thus, school, peer group and family's role in this case plays a crucial role in the formation of moral attitude (Dushi, n.d). Beside experience is also culture as a factor that form the moral behaviour as pointed out by Amstrong (1996), that there is a relationship between cultural dimension and ethical perception. It is strongly believed that social and cultural atmosphere affects the moral development of a child and this is the reason why individual from different cultural background behave differently with other individual 
from other cultures (Dushi, n.d). This argument has been founded on the argument of Hofstede on the influence of culture over the development of Hofstede as cited by Brown (1995), that culture plays important role in the brain functioning and brain structure.

Based on the above argument, the researcher believes that Catholic students' attitude toward morality is influenced by their own exposure toward family, school, peer and cultural values. Family and school are playing important role on the moral formation of a kid as stated by Clipa and Lorga (2013).Thus, it is recommended that there must be a close partnership between the family and school in terms of moral formation of children. Beside family and school, peer group also plays an important role on the moral development of a kid as pointed out by Blazevic (2016) that school-aged children interact with same-sex peer groups. Children of the same age will tend to have the same fondness and enjoy more time together. This interaction process forms the child into a better person or vice versa depending on the kind of group they are associating with. The same importance is the influence of the culture over the moral development of a kid. The reason why there is a difference in judgment of morality because of cultural differences (Graham, et.al, 2015). This cultural factor includes religion as one of the factors influence the moral formationof a kid.

In the Philippines context, the role of religion in the moral formation can never be ignored. Hence, the role of the Catholic Church in the Philippine history cannot be denied. Since the colonial period or Spanish Colonialism, Catholicism has been the cornerstone of Filipino identity for millions of the population (Harvard Divinity School, 2019). Thus, it cannot be denied that religion has influenced the life of many Filipinos. It has been very influential factor in society (Delgado, 2004), which is not only limited to politics, arts and society but it has very strong influence on the moral values of Filipinos (Ochoa, Sio, Quinones \& Manalastas, 2016), though recent development indicated decreased influence of the Catholic Church on morality issues as the case of reproductive health bill which majority support the bill. Traditionally they looked up to the Church for political and moral guidance but current development the power of the Church seems to be diminished (Strother, 2013). Such development seems to indicate a change of attitude toward the Catholic Church. Nevertheless, in the context of the Philippine society, social psychological factor such as the interplay of religiosity and morality may influence public opinion on issues, which may have an impact on how people perceived issues on morality. But the question of the extent of the influence of the Catholic Church toward morality of Filipinos remain uncertain as indicated by Cardinal Quevedo as cited by Montelibano (2017) in the Daily Inquirer. It is admitted that there is a reversed trend in the way how Filipinos are living, though they seem to be religious but their lives seem to be otherwise. Filipinos have the idea of morality;they know about what is good and bad or right or wrong but their behaviour may not necessarily go along with their stand or their words. This is pointed out in the survey of Pew Research Centre as cited by Go (2015) in Rappler, that Filipinos remain a morally conservative compared to other societies (40 countries) on the 8 moral issues such as extramarital sex, gambling, homosexuality, abortion, pre-marital sex, alcohol consumption, divorce and use of contraceptives but this moral conservative stand does not really mean that they live according to what they believe. The reason behind this contradiction may be found in the argument of Gorospe (1977) that there is a contradiction between actual and prevailing moral norms as Christians and with what they do. Gorospe (1977) pointed out that the reason behind this contradiction is that Filipinos have not reached individual moral independence but morality is based on the consensus of the group. It is the group that determines right and wrong or good and bad. Moral decisions are made in accordance with the expectation of the group, family, peer group or "barkada".Consequently, morality will be based on popularity in which a good act would be based on the public approval.

Going into the statistic of population, it shows that the total population of the Philippines is 105, 000,000 (Rappler, 2014) with its Catholic population of $81, .4 \%$ of the total population (Pew Research Centre, 2011). Such figures seem to indicate that majority of the Filipinos are adhering to and influenced by the teaching of the Catholic Church on morality. But as pointed out above that the current development indicates that the moral power of the Catholic Church is slipping (Strother, 2013), and group morality prevails, though other may still see the Catholic Church remains a social force with a moral high ground for political transformation (Cartagenas, 2015) but not necessarily for moral transformation. It is also interesting to see at one point that thoughthe Philippines is dominated by Catholic religion but it is still secular nation because the Church does not interfere in the government and the Constitution guarantees the separation between the Church and the state. The government in this case does not intervene in the business of the Church and its teaching (Batalla \& Baring, 2019).

The Concept of Academic Cheating and Its Morality 
Academic cheating is not isolated case because cheating has penetrated in all areas of human endeavours. It does not happen only in the business but it happens in the government, in the school and even in the sports (Ethical System.Org, n.d). Case like not paying the right amount of taxes, stealing money from employers, cheating office time, spending public money for personal interest, cheating on exams during examination time, etc. becomes ordinary way of life. Not knowing that these immoral acts can cause a lot of damages to the business in the process and cause affect the quality and consequently lead to bankruptcy in business but in terms of cheating in the school can lead to low quality of graduates. Academic cheating is a violation of academic integrity and it can be confined within certain acts such as using another person's work as his own, taking the answers from others during the exam, allowing someone to use one's work during the examination or in assignment, getting an advanced look at the examination test or getting questions in advance, copying material without citation, possessing notes or answers in advance of an examination, using electronic device to get information during the exam, doing the exam for someone else or having someone to perform the exam for you (Pecorino, 2017). These are all academic dishonesty and dishonesty is immoral.

In relation to academic cheating, there can be two kinds of cheating which is planned cheating and panic cheating (Grijalva, et.al, 2006). Planned cheating means that the students plan to cheat intentionally. They know that cheating is wrong but they still do it and therefore they do it knowingly and willingly. It is different in the case of panic cheating. In this case, the situation forces the student into cheating. In the case of panic cheating, the students cheat out of desperation. They want to pass the exam but they do not know the answer and they turn to easy way which is to cheat. In this case cheating can be the only means to control the situation that is slipping away from them (Ozar, 1991). The behaviour is encouraged when the teachers is ignoring the cheating behaviour even though he/she knows. Such behaviour can be multiplied to other students if it is not prevented through punishment (McCabe, 2005). When the students are not punished, then there is a tendency to repeat such behaviour. According to some studies that the main motivation why students copy or cheat during the exam is because they want to pass the exam and want to have a higher grades and according to the study that in the situation in which the students aspire for higher grades, it is hard for them to understand or to accept that cheating is unethical (Bertolami, 2004).This unethical behaviour is reinforced when the students know that there is a reward after doing it. The person will enjoy doing it when he/she knows that he/she stand to gain from such behaviour (Mills, 1958).

\section{RELATED STUDIES}

Concerns on youth's morality has been raised by many researchers around the globe because they are the future generations of certain country or state. The survival of a country depends of the quality of its people and its leadership. It is not surprising if curriculum developers incorporate morals, values, ethics and character education in the curriculum. Rapid changes in the society because of the technology contribute to the complexities of social life and underpinning the importance of morals, values and ethic (Chowdhury, 2016). Therefore, the concern of older generation is preparing the youth who are future leader. Preparations for leadership is not only addressing technical skills but particularly moral character. Thus, it is imperative for the youth to acquire moral standards and values that will mold them into personalities ready to lead for the progress of the society (George \& Uyanga, 2014). Along this concern, Lodhi and Siddiqui (2014) conducted a study on the attitude of Students towards Ethical and Moral Values in Karachi, Pakistan. The finding of the study had mixed results. Several results were pointed out that majority of students have positive attitude toward ethics but it seems that such ethical attitude does not translate into their moral behaviour because majority have uncaring attitude, and want to have their own rules. Many students have not also learned ethics. From such findings, it was recommended that moral education must be imparted to all the school going children to develop ethical practices.

The finding above indicate the fact that students might have different view about morality and these differences can be caused by cultural differences. Thus, along such concern, Gholamzedehmir (2015) examined the attitude toward morality. According to his study, moral attitude of UK and Iran are different because both countries have different cultural background. The result of such study confirms the important point of morality that absolutism or universalism is not applicable which is contrary to Immanuel Kant. But the study pointed out the major point that morality or moral norms are different from both countries and that moral norms were a more useful predictor of intention. This finding leads us to the finding of Forsyth, and Berger (2010) on the effect of ethical ideology on the judgment of moral behaviour, particularly on cheating behaviour. There were several ethical ideologies investigated which include absolutists 
(nonrelativistic and idealistic), exceptionists (nonrelativistic and pragmatic), situationists' (relativistic and idealistic), subjectivists (relativistic and pragmatic). The study found that students who adopt absolutism were more pronounced on their judgment of morality compared to those who adopt situational morality. Those who adopt such ideology have no clear idea on the morality of their behaviour. Interestingly, exceptionists, who adopt nonrelativistic and pragmatic view are experiencing increased happiness when they cheat, the more they cheat, and the happier they are. While subjectivists (relativistic and pragmatic) show sign of fear of detection. Thus, the study conclude that moral judgment is depending on the ideologies they are holding.

In relation to the different ethical ideology of Forsyth, and Berger (2010) on the moral judgment, Eisenberg (2007) tried to investigate the effects of different moral perspective toward cheating behaviour, whether they cheat or not to cheat. The study found that a-morally oriented students approved significantly more of cheating than morally oriented students. The result of this study proves the importance of morality to influence moral behaviour. This Conceptual Framework

Independent Variables finding is also confirmed by the study of Lucidi, et.al (2017) on the moral attitude and cheating among competitive tennis players. The study was based on the hypothesis that moral attitudes would directly predict actual cheating behaviour observed during match play. The study found to confirm the hypothesis that there is a relationship between moral attitude and cheating behaviour. In relation to academic cheating, the study of Sharath, et.al (2013) pointed out the reason why students are cheating and the solution of teachers for preventing cheating. Sharath, et.al (2013) on their study on attitudes of students and teachers on cheating behaviours pointed out the main reason why students cheat is because they want to pass the exam and to attain better grade. On the part of the solution of the teacher to prevent cheating is warning and counselling and not punishment in order for the students to restore their moral values. However, Sanwong (2010) as a result of his study on moral based thinking process skills for students' morality and ethics development recommended moral-based thinking process skill teaching methodology to develop students' morality.

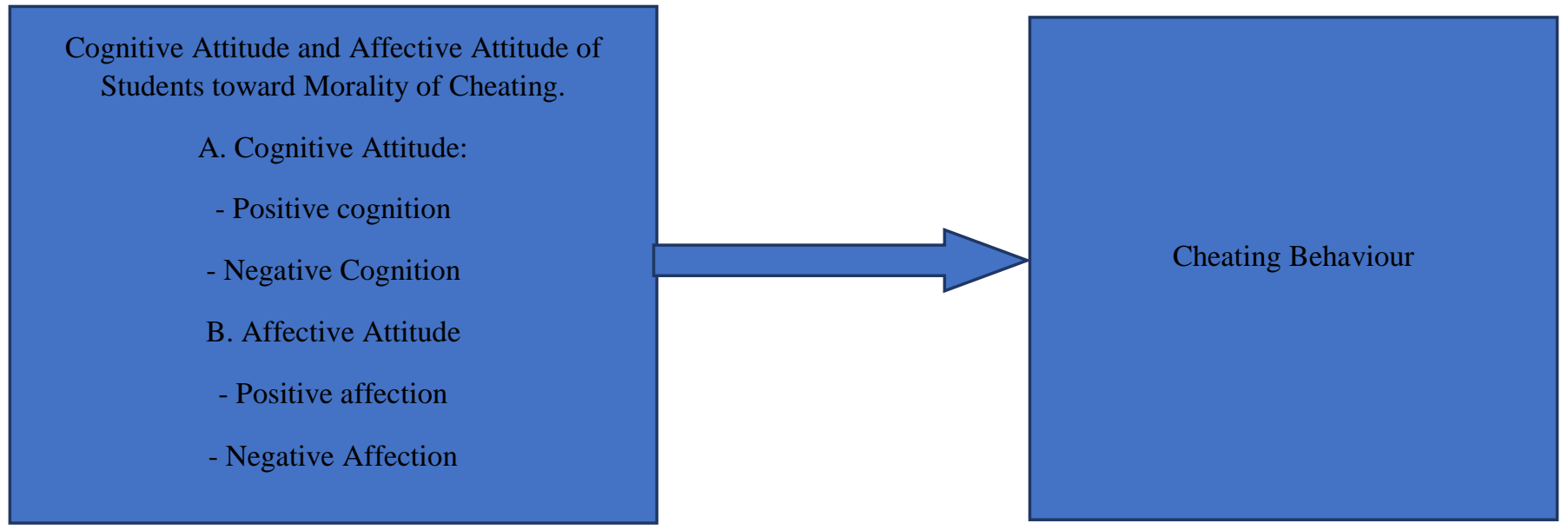

Fig.1: The conceptual framework indicates the concept of the study that there is relationship between independent variables and dependent variables. Independent variables such as cognitive attitude and affective attitude affect the cheating behaviour of students.

\section{Statement of the Problems}

The study wanted to determine the relationship between attitude of students toward morality of cheating and their actual cheating behaviour. Specifically, it seeks to answer the following questions:

1. What is the positive and negative cognitive attitude of students toward morality of cheating?
2. What is the positive and negative affectionof students toward morality of cheating?

3 . What is the cheating behaviour of students?

4. Is there a relationship between cognitive and affective attitude and cheating behaviour of the students?

\section{Assumptions}

The study assumes that theories are correct and follow the methodological procedures in carrying out the study. It is 
also assumed that questionnaires are validated and the answers are objectives.

\section{Hypothesis}

Ajzen (1985, 1987), Ajzen and Madden, (1986) have argued that attitudes affect the human behavior and base on this theory, the current study argues that attitudes of students toward morality of cheating affect their cheating behaviour.

\section{Scope and Delimitation of the Study}

The study limits itself to measure the attitude of students toward morality of cheating of Catholic Senior High School students and their cheating behaviour in the Divine Word Colleges in Ilocos Region run by the SVD Priests.

\section{RESEARCH METHODOLOGY}

\section{Methodology}

The study was carried out through appropriate research methodology such as research design, data gathering instruments, population, locale of the study, data gathering procedures and statistical treatment of data.

\section{Research Design}

Since the study is a quantitative research and therefore it used descriptive correlational research designand aided by inquiry to determine the level of attitudes of students toward morality of cheating and cheating behaviour of students. The nature of descriptive research is to describe what is found in the data collected through questionnaires and statistical treatment. It is also used to describe profiles, frequency distribution, describe characteristics of people, situation, phenomena or relationship variables. In short, it describes "what is" about the data (Ariola, 2006, cited by Abun, 2019).

In line with the current study, descriptive correlational method was deployed. The study determines the level of attitude toward morality of cheating and its correlation with the cheating behaviour of students. This was to determine what the dominant attitude of students toward morality of cheating were and what particular attitudes affects the cheating behaviour.

\section{Locale of the Study}

The locale of the study was Senior High School of the Divine Word Colleges in Ilocos Region which is composed of Divine Word College of Vigan and Divine Word College of Laoag. Divine Word College of Vigan is belonged to the Province of Ilocos Sur and located within the heritage city of Vigan. Divine Word College of Laoag is located in Laoag City, Ilocos Norte. Divine Word Colleges in Region I are run by the Congregation of the Divine Word
Missionaries or known as Society of the Divine Word or in Latin, Societas Verbi Divini (SVD).

\section{Population}

The population of the study was composed of all grade XIIof Senior High School students of Divine Word Colleges in Ilocos region. Since the total numbers of students are limited, and therefore total enumeration is the sampling design of the study.

\section{Data Gathering instruments}

The study utilized validated questionnaires. The questionnaires were adapted from Joshua Trent Kline, (2017) on Morality, Cheating and the Purpose of Public Education and its content was further validated by the expert on the subject matter.

\section{Data Gathering Procedures}

In the process of data gathering, the researcher sent letters to the President of the Colleges, requesting them to allow the researcher to flow his questionnaires in the college. The researcher personally met the Presidents and requested students to answer the questionnaires.

The retrieval of questionnaires was arranged between the President's representative and the researcher with the help of employees and faculty of the college.

\section{Statistical Treatment of Data}

In consistent with the study as descriptive research, therefore descriptive statistics was used. The weighted mean is used to determine the level of attitude of students toward morality of cheating andtheir cheating behaviourand the Pearson $r$ was used to measure the correlation of attitudes toward morality of cheating and the cheating behaviour of the students

The following ranges of values with their descriptive interpretation will be used:

\section{Statistical Range}

Descriptive Interpretation Overall Descriptive Rating

4.21-5.00: $\quad$ Strongly agree/strongly disagree

Very High/very low

3.41-4.20:

Agree/Disagree High/low

2.61-3.40:

Somewhat agree/somewhat disagree

Moderate/moderate

1.81-2.60: Disagreelagree Low/High

1.00-1.80:Strongly disagree/strongly agree Very Low/Very High

\section{FINDINGS}

The presentation of the findings of the study is structured according to the arrangement of the statement of the 
problems. The study was interested in finding out the correlation between cognitive and affective attitude of students toward the morality of cheating and their cheating behaviours. To investigate such objective, several statement of the problems were proposed.

Problem 1: 1. What is the positive and negative cognitive attitude of students toward morality of cheating?

Table 1. Positive and Negative Cognitive Attitude of Students toward Morality of Cheating

\begin{tabular}{|l|c|l|}
\hline A. Cognitive Attitude on Cheating & Mean & DR \\
\hline Positive Attitude & 3.70 & A \\
\hline 1. Cheating is equal with dishonesty. & 3.90 & A \\
\hline 2. As a Catholic student I know that cheating is morally wrong. & 4.00 & A \\
\hline 3. Honesty is the best policy in exam. & 3.40 & SWA \\
\hline 4. Help someone during the test is good. & 3.60 & \\
\hline 5. Copy pasting the work of others without recognizing the author is morally wrong. & A \\
\hline 6. Cheating is against the ten commandments of God (8). $^{\text {th) }}$ & 3.60 & A \\
\hline 7. Cheating is morally accepted because it is common among students. & 2.90 & SWA \\
\hline Weighted Mean & $\mathbf{3 . 5 9}$ & A \\
\hline Negative Attitude & 2.10 & D \\
\hline 1. Morality is not important. & 2.60 & D \\
\hline 2. I am not sure if cheating is morally wrong because many people have been doing it. & 2.60 & D \\
\hline 3. I do not know if plagiarism is morally wrong. & 2.70 & SWA \\
\hline 4. I am not sure if helping someone to pass the test is not good. & 2.60 & D \\
\hline 5. I am not certain if cheating is against the $8^{\text {th }}$ commandment of God. & 2.60 & D \\
\hline 6. Cheating is not morally wrong because people have been doing it. & 2.70 & SWA \\
\hline 7. I do not know if helping someone during a test is also immoral. & $\mathbf{2 . 5 6}$ & D \\
\hline Weighted Mean & \\
\hline
\end{tabular}

Legend:

4.21-5.00: Strongly agree/strongly disagree

3.41-4.20: Agree/Disagree

2.61-3.40: Somewhat agree/somewhat disagree

1.81-2.60: Disagree/agree

1.00-1.80: Strongly disagree/strongly agree

Very High/very low
High/low
Moderate/moderate
Low/High
Very Low/Very High

cheating is morally accepted because it is common among students (2.90).

Looking into negative cognitive attitude, as a whole, the data manifests that negative cognitive attitude of students toward morality of cheating is 2.56 which means disagree. Students support their positive cognitive attitude toward the morality of cheating. Thus, taking it singly, it shows that the students disagree that "morality is not important" (2.10), " I don't know if plagiarism is morally wrong" (2.60), "I am not sure if cheating is morally wrong because many people have been doing it" (2.60), "I am not certain if cheating is against the $8^{\text {th }}$ commandment of God" (2.60), "Cheating is not morally 
wrong because people have been doing it" (2.60) and somewhat agree that they are not sure if helping someone to pass the test is not good" (2.70) and if helping someone during a test is also immoral (2.70).

Problem 2: What is the positive and negative affection of students toward morality of cheating?

Table.2. Positive and Negative Affection of Students toward Morality of Cheating

\begin{tabular}{|l|c|l|}
\hline B. Affective Attitude on Cheating & Mean & DR \\
\hline Positive Attitude & & \\
\hline 1. As long as I pass the examination, I am happy, I do not care if cheating is good or bad. & 2.81 & SWA \\
\hline 2. I am excited to pass the exam even if cheating is bad. & 2.80 & SWA \\
\hline 3. It feels good to have high grades even if cheating is not good. & 2.81 & SWA \\
\hline 4. I feel bad if I pass the exam because of cheating. & 3.31 & SWA \\
\hline Weighted Mean & $\mathbf{2 . 9 3}$ & SWA \\
\hline Negative Attitude & & \\
\hline 1. I do not feel good if I pass the exam because of cheating. & 3.24 & SWA \\
\hline 2. I do not feel ashamed to my friends if I passed the exam because of cheating. & 2.82 & SWA \\
\hline 3. I am not excited to receive high grades because of cheating. & 3.25 & SWA \\
\hline 4. I am not proud to be given academic award because I know that I cheated. & 3.26 & SWA \\
\hline Weighted Mean & $\mathbf{3 . 1 4}$ & SWA \\
\hline
\end{tabular}

Legend:

4.21-5.00: Strongly agree/strongly disagree

3.41-4.20: Agree/Disagree

2.61-3.40: Somewhat agree/somewhat disagree

1.81-2.60: Disagree/agree

1.00-1.80: Strongly disagree/strongly agree
Very High/very low

High/low

Moderate/moderate

Low/High

Very Low/Very High
As it is shown on the table, the data reveals that as a whole, students' positive affection toward the morality of cheating is 2.93 which means somewhat agree. Even when the questions are taken singly, it shows that students somewhat agree that "As long as I pass the examination, I am happy, I do not care if cheating is good or bad" (2.81), "I am excited to pass the exam even if cheating is bad (2.80), "It feels good to have high grades even if cheating is not good" (2.81), "I feel bad if I pass the exam because of cheating" (3.31).

It is also the same evaluation on their negative affection. Taking it as a whole, the data shows that students' negative affection toward morality of cheating is 3.14 which means somewhat agree. This assessment is supported by individual question. When taking it singly, it reveals that students somewhat agree that "I do not feel good if I pass the exam because of cheating" (3.24), "I am not excited to receive high grades because of cheating" (3.25), and "I am not proud to be given academic award because I know that I cheated" (3.26) but somewhat agree too "I do not feel ashamed to my friends if I passed the exam because of cheating" (2.82).

The above data shows that there is a mixed feelings toward the morality of cheating. At one hand, students know cheating is bad and they are not feeling good about it but they are also happy when they pass the exam even if it means they pass because of cheating.

\section{Problem 3: What is the cheating behaviour of students?}

Table 3. The Cheating Behaviour of Students

\begin{tabular}{|l|l|l|}
\hline C. Cheating Behaviour & Mean & DR \\
\hline 1. I copied from another student during a test or exam. & 2.95 & SWA \\
\hline 2. I Used unpermitted crib notes (or cheat sheets) during a test or exam. & 2.32 & D \\
\hline 3. I got questions or answers from someone who had already taken a test. & 2.44 & D \\
\hline
\end{tabular}


4. I am using an electronic or digital device (e.g. cell phone) as an unauthorized aid during an exam.

5. I helped someone else cheat on a test.

6. I turned in work I copied from another student.

$2.20 \mathrm{D}$

7. I turned in an assignment on which my parents did most of the work.

8. I claimed credit for group work when I really didn't contribute.

9. I copied a few sentences from a site on the Internet without citing them.

10. I copied a few sentences from a book, magazine, or other source without citing them.

Weighted Mean

Legend:

4.21-5.00: Strongly agree/strongly disagree

3.41-4.20: Agree/Disagree

2.61-3.40: Somewhat agree/somewhat disagree

1.81-2.60: Disagree/agree

1.00-1.80: Strongly disagree/strongly agree
Very High/very low

High/low

Moderate/moderate

Low/High

Very Low/Very High
As it is reflected on the table, the data reveals that as a whole, cheating behaviours of students is 2.49 which means disagree. Even when taking the questions singly, it shows that the students disagree that "they used unpermitted crib notes (cheat sheets) during a test or exam (2.32), "got questions or answers from someone who had already taken a test" (2.44), "are using an electronic or digital device (e.g. cell phone) as an unauthorized aid during an exam" (2.20), "are using an electronic or digital device (e.g. cell phone) as an unauthorized aid during an exam" (2.20), "turned in work
I copied from another student" (2.51), "turned in an assignment on which my parents did most of the work"(2.37), "claimed credit for group work when I really didn't contribute" (2.42), "copied a few sentences from a site on the Internet without citing them" (2.58), and "copied a few sentences from a book, magazine, or other source without citing them" (2.48). But they somewhat agree that they "helped someone else cheat on a test" (2.62), and "copied from another student during a test or exam" (2.95).

Problem 4: Is there a relationship between cognitive and affective attitude and cheating behaviour of the students?

Table 4. Relationship between Cognitive and Affective attitude and Cheating behaviour of the Students

\begin{tabular}{|c|c|c|c|c|c|c|}
\hline & & $\begin{array}{l}\text { Cognitive } \\
\text { Positive }\end{array}$ & $\begin{array}{l}\text { Cognitive } \\
\text { Negative }\end{array}$ & \begin{tabular}{|l} 
Affective \\
Positive
\end{tabular} & $\begin{array}{l}\text { Affective } \\
\text { Negative }\end{array}$ & $\begin{array}{l}\text { Cheating } \\
\text { Behaviour }\end{array}$ \\
\hline \multirow{3}{*}{$\begin{array}{l}\text { Cognitive Attitude } \\
\text { on Cheating - } \\
\text { Positive }\end{array}$} & Pearson Correlation & 1 & $-.214^{* *}$ & .048 & $.156^{* *}$ & $-.198^{* *}$ \\
\hline & \begin{tabular}{|l} 
Sig. (2-tailed) \\
\end{tabular} & & .000 & .415 & .008 & .001 \\
\hline & $\mathrm{N}$ & 288 & 288 & 288 & 288 & 288 \\
\hline \multirow{3}{*}{$\begin{array}{l}\text { Cognitive Attitude } \\
\text { on Cheating - } \\
\text { Negative }\end{array}$} & Pearson Correlation & $-.214^{* *}$ & 1 & $.240^{* * *}$ & $.126^{*}$ & $.271^{* *}$ \\
\hline & Sig. (2-tailed) & .000 & & .000 & .033 & .000 \\
\hline & $\mathrm{N}$ & 288 & 288 & 288 & 288 & 288 \\
\hline \multirow{3}{*}{$\begin{array}{l}\text { Affective Attitude } \\
\text { on Cheating - } \\
\text { Positive }\end{array}$} & Pearson Correlation & .048 & $.240^{* *}$ & 1 & $.137^{*}$ & $.365^{* *}$ \\
\hline & Sig. (2-tailed) & .415 & .000 & & .020 & .000 \\
\hline & $\mathrm{N}$ & 288 & 288 & 288 & 288 & 288 \\
\hline \multirow{3}{*}{$\begin{array}{l}\text { Affective Attitude } \\
\text { on Cheating - } \\
\text { Negative }\end{array}$} & Pearson Correlation & $.156^{* *}$ & $.126^{*}$ & $.137^{*}$ & 1 & .005 \\
\hline & Sig. (2-tailed) & .008 & .033 & .020 & & .937 \\
\hline & $\mathrm{N}$ & 288 & 288 & 288 & 288 & 288 \\
\hline \multirow{3}{*}{$\begin{array}{l}\text { Cheating } \\
\text { Behaviour }\end{array}$} & Pearson Correlation & $-.198^{* *}$ & $.271^{* *}$ & $.365^{* *}$ & .005 & 1 \\
\hline & Sig. (2-tailed) & .001 & .000 & .000 & .937 & \\
\hline & $\mathrm{N}$ & 288 & 288 & 288 & 288 & 288 \\
\hline
\end{tabular}

**. Correlation is significant at the 0.01 level (2-tailed).

*. Correlation is significant at the 0.05 level (2-tailed). 
As reflected on the table of correlation, the data reveals that there is a significant correlation at the 0.01 level (2-tailed) between positive cognitive attitude toward morality of cheating and cheating behaviour of students $\left(-.198^{* *}\right)$. It is also manifested on the correlation table that there is a significant correlation at 0.01 level (2-tailed) between negative cognitive attitude toward the morality of cheating and cheating behaviour of students $\left(.271^{* *}\right)$. It also further shows that there is a significant correlation at the 0.01 level (2-tailed) between positive affective attitude or positive affection toward the morality of cheating and cheating behaviour $\left(.365^{* *}\right)$ and lastly, there is no significant correlation at 0.01 level (2-tailed) between negative affective attitude or negative affection toward morality of cheating and cheating behaviour of students.

\section{CONCLUSION}

Based on the findings, the study finally concludes that positive cognitive attitude of students toward the morality of cheating is considered high and this is supported by their negative cognitive attitude in which its rating is considered low. Low rating in the negative cognitive indicates that the students confirm their positive cognitive attitude toward the environment.

On the affective attitude, the study found that students' positive affective attitude toward the morality of cheating is considered moderate and it is also the same on the negative affective attitude. In other words, positive and negative feeling toward the morality of cheating is considered moderate.

While in terms of their academic cheating behaviour, the study found that students' cheating behaviour is considered low. As compared to their positive cognitive attitude toward morality of cheating which was assessed to be in the average of 3.59 which means agree or high, however, their cheating behaviour is 2.49 which means disagree or low.

Finally, the Pearson $r$ correlation found that there is a correlation between positive and negative cognitive attitude toward the morality of cheating and their cheating behaviour. The correlation was also found between positive affective attitude toward morality of cheating and cheating behaviour of students. However, negative affective attitude was found not to be correlated to the cheating behaviour of students.

\section{REFERENCES}

[1] Abbott, Th.K. (trans.), (1889). Immanuel Kant, The Metaphysical Elements of Ethics, (Preface and Introduction to Metaphysische Anfangsgründe der Tugendlehre, 1797). Project Gutenberg. p. 23.
[2] Abun, D. (2017). Environmental Attitude and Environmental Behaviour of Catholic Colleges' Employees in Region I, Philippines. Texila International Journal of Academic Research, Vol. 4, Issue 1, June, 2017.

[3] Abun, D. (2017). Measuring Environmental Attitude and Environmental Behaviour of Senior High School Students of Divine Word Colleges in Region I, Philippines. EPH International Journal of Educational Research, Volume-1 | Issue2| July,2017 | Paper-2.

[4] Ajzen, I., \& Fishebin, M. (1980). Understanding attitude and predicting social behaviour. Englewood-Cliffs, NJ: Prentice-Hall.

[5] Ajzen, I., Madden, T.J. (1986). Prediction of Goal Directed Behaviour: Attitudes, Intentions and Perceived Behavioural Control. Journal of Experimental Social Psychology, 22, 453-474.

[6] Ajzen, I. (1993). New Directions in Attitude Measurement. New York: Walter de Gruyter.

[7] Ajzen, I., \& Fishbein, M. (2000). Attitudes and the AttitudeBehaviour relation: Reasoned and Automatic Processes. In W. Stroebe \& M.Hewstone (Eds.). European Review of Social Psychology, Vol. 11, pp. 1-33. Chichester, UK: Wiley.

[8] Ajzen, I., \& Fishbein, M. (1977). Attitude - Behaviour Relations: A Theoretical Analysis and review of Empirical Research. Psychological Bulletin, 84, 888-918.

[9] Ajzen, I. (1985). From Intention to Action: A Theory of Planned Behaviour. In Kuhl, J., Beckmann, J., (Eds). Action Control: From Cognition to Behaviour. Heidelberg: Springer.

[10] Ajzen, I. (1987). Attitudes, Trait and Action: Dispositional Prediction of behavior in Personality and Social Psychology. In Berkowitz, L. (Ed.). Advances in Experiential Social Psychology, Vol. 20, pp. 1-63. New York: Academic Press

[11] Ajzen, I., \& Fishbein, M. (2015). The Influence of Attitude on Behaviour. University of Pennsylvania: Annenberg School for Communication.

[12] Allport, G.W. (1935). Attitudes. In C. Murchison (Ed). Handbook of Social Psychology. Worcester, MA: Clark University Press.

[13] Allport, G.W. (1968). The Historical background of Modern Social Psychology. In G. Lindzay and E. Aronson (Eds.). Handbook of Social Psychology. Reading, MA: Addison-Wesley.

[14] Allport, G.W. (1954). The Historical Background of Modern Social Psychology. In Lindzay, G. (Ed.). Handbook of Social Psychology, Vol. 1, pp. 3-56. Cambridge, MA: Addison-Wesley.

[15] Amstrong, W. R. (1996). The Relationship between Culture and Perception of Ethical Problems in International Marketing, Journal of Business Ethics, Volume: 15, Issue: 11, Pages: 11991208.

[16] Ariola, M.M. (2006). Principles and Methods of Research. Manila: National Bookstore.

[17] Banaji, M.R. \& Heiphetz, L. (2010). Attitudes. In S.T. Fiske, D.T. Gilbert \& G. Lindzey (Eds). Handbook of Social Psychology $\left(5^{\text {th }}\right.$ ed, Vol. 1, pp. 353-393. Hoboken, NJ: John Wiley \& Sons.

[18] Bandura, A.; Adams, N. E.; Hardy, A. B.; Howells, G. N. (1980). "Tests of the generality of self-efficacy theory". Cognitive Therapy and Research. 4 (1): 39-66. doi:10.1007/bf01173354.

[19] Batalla, E.V. \& Baring, R. (2019). Church-State Separation and Challenging Issues Concerning Religion. MDPI Journal of Religions. doi:10.3390/rel10030197. 
[20] Bem, D.J. (1970). Beliefs, Attitudes and Human Affairs. Belmont, CA: Brooks/Cole.

[21] Bertolami, C.N. (2004). Why our ethics curricula don't work.Journal of Dental Education April 2004, 68 (4) 414-425;

[22] Bilz, K. \& Nadler, J. (2014). L AW, MORAL, AT TITUDES, AND BEHAVIORAL CHANGE. In Zamir, E. and Teichman, D, (Eds.), (2014). The Oxford Handbook of Behavioural Economics and the Law. Retrieved from https://www.law.northwestern.edu/faculty/fulltime/nadler/BilzNadler-LawMoralAttitudesPageProofs.pdf.

[23] Blazevic I. (2016). Family, peer, and school influence on children's social development. World Journal of Education, 6(2), 42-49. doi:10.543/wje. v6n2p42.

[24] Brown, A. (1995). Organizational Culture. London: Pitman Publishing.

[25] Cartagenas, A. (2015). Religion and Politics in the Philippines: The Public Role of the Roman Catholic Church in the Democratization of the Filipino Polity. Journal of Political Theology, Vol. 11, 2010, Issue 6.

[26] Catholic Encyclopedia (n.d): Teleology. Retrieved from www.newadvent.org. Retrieved 2019-06-19.

[27] Cherry, K. (2019). Attitude and Behaviour in Psychology. Very Well Mind. Retrieved from https://www.verywellmind.com/what-is-self-esteem-2795868.

[28] Chowdhury, M. (2016). Emphasizing Morals, Values, Ethics, And Character Education in Science Education and Science Teaching. The Malaysian Online Journal of Educational Science 2016, Volume 4, Issue 2.

[29] Clipa, O., \& Lorga, A.M. (2013). The Role of Family-School Partnership in Moral Development. Procedia-Social and Behavioural Sciences, Vol. 76, pp. 197-203

[30] Corey, S. M. (1937). Professed attitudes and actual behaviour. Journal of Educational Psychology, 28(4), 271280.http://dx.doi.org/10.1037/h0056871.

[31] Dean, L. R. (1958). Interaction, reported and observed: The case of one local union. Human Organization, 1958,17, 36-44.

[32] DeFleur, M.L. \& Westie, F.R. (1958). Verbal Attitude and Overt Acts: An Experiment on the Salience of Attitude. American Sociological Review 23(6):667.

[33] Delgado, K. (2004). Influences of Christianity to Filipino Culture. Asian Civ. $\quad$ Retrieved from https://www.scribd.com/doc/20517008/Influences-ofChristianity-to-Fil-Culture\#download.

[34] Deutscher, I. (1968). Looking Backward: Case Study on the Progress of methodology in sociological research. American Sociologist, Vol. 4, 35-41.

[35] Donald, M. (2002). A Mind So Rare: The Evolution of Human Consciousness. New York: W.W. Norton \& Company, Inc.

[36] Dushi, G. (n.d). Six Factors that Affect the Moral Development of a Child. Retrieved from http://www.preservearticles.com/education/six-factors-thataffects-moral-development-of-a-child/18098.

[37] Edwards, A.L. (1957). Technique of Attitude Scale Construction. New York: Appleton-Century-Crofts.
[38] Eisenberg, J. (2007). To cheat or not to cheat: effects of moral perspective and situational variables on students' attitudes. Journal of Moral Education, 33 (2):163-178 (2004).

[39] Ethical System.Org (n.d). Cheating \& Honesty. Business Integrity Through Research. Retrieved from https://www.ethicalsystems.org/content/cheating-honesty.

[40] Fishbein, M., Ajzen, I. (1975). Belief, Attitude, Intention and behaviour: An Introduction to Theory and Research. Reading, MA: Addison-Wesley.

[41] Flew, A. (1979). "Consequentialism". In A Dictionary of Philosophy (2nd Ed.). New York: St Martins: 73.

[42] Forsyth, D. R \& Berger, R. E (2010). The Effects of Ethical Ideology on Moral Behaviour. The Journal of Social Psychology, Vol. 117, Issue 1, 2010.

[43] Freeman, L. C., \& Ataoev, T. (1960). Invalidity of indirect and direct measures of attitude toward cheating. Journal of Personality, 28, 443-447.

[44] Gardner, W. M. \& Melvin, K. B. 91988). The Attitude Toward Cheating Scale Opinion Questionnaire. Bulletin of the Psychonomic Society /988, 26 (5), 429-432.

[45] George, I.N., \& Uyanga, U.D. (2014). Youth and Moral Values in a Changing Society. IOSR Journal of Humanities and Social Science (IOSR-JHSS) Volume 19, Issue 6, Ver. I (Jun. 2014), PP 40-44.

[46] Gholamzedehmir, M. (2015). The Impact of Moral Action and Moral Values on Moral Judgment and Moral Behavior. Unpublished Thesis: University of Sussex.

[47] Grijalva TC, Nowell C, Kerkvliet J. (2006). Academic honesty and online course. College Student Journal 2006;40(1):180-6.

[48] Go, M.G.A. (2015). Abortion, Affairs top Moral No No"s for Filipinos-Survey. Rappler. Retrieved from https://www.rappler.com/nation/80704-pew-research-surveymorality-philippines.

[49] Gorospe, V. R. (1977) Sources of Filipino Moral Consciousness. JSTOR, Vol.25, No. 3, pp. 278-301

[50] Graham, J., Meindl, P., Beall, E., Johnson, K.M. \& Zhang, L. (2015). Cultural Differences in Moral Judgment and behaviour, Across and Within Societies. University of Southern California: Current Opinion in Psychology.

[51] Harvard Divinity School (2019). Catholicism in the Philippines. Religious Literacy Project. Retrieved from https://rlp.hds.harvard.edu/faq/catholicism-philippines.

[52] Hemma, K.E. (n.d). Natural Law. Internet Encyclopedia of Philosophy. Retrieved fromhttps://www.iep.utm.edu/natlaw/.

[53] Kline, J.K (2017). Morality, Cheating and the Purpose of Public Education. Theses and Dissertations. Lehigh University.

[54] Lawler, M.S. (2006). William James's psychological pragmatism: habit, belief and purposive human behaviour. Cambridge Journal of Economics, Vol. 30, No. 3 (May 2006), pp. 321-345.

[55] Lodhi, M.S.\& Siddiqui, J.A. (2014). Attitude of Students towards Ethical and Moral Values in Karachi, Pakistan. IOSR Journal of Research \& Method in Education (IOSR-JRME). Volume 4, Issue 2 Ver. IV (Mar-Apr. 2014), PP 07-11.

[56] Lucidi,F., Zelli, A., Mallia, L., Nicolais, G., , Lazuras,L., \&Hagger, M.S. 2017. Moral Attitudes Predict Cheating and Gamesmanship Behaviours Among Competitive Tennis Players. 
Frontiers in Psychology, 12 April, 2017/https://doi.org/10.3389/fpsyg.2017.00571.

[57] Martin, M.W. (1981). Professional and Ordinary Morality: A Replay to Freedman. Ethics: An International Journal of Social, Political and Legal Philosophy, Vol. 91, Number 4, 1981.

[58] McCabe, D. (Obituary). (2016). Star-Ledger. Retrievedfrom http://obits.nj.com/obituaries/starledger/obituary.a spx?pid=181490279.

[59] McCabe, D. (2005). Cheating: Why students do it and how we can help them stop. London: Libraries Unlimited.

[60] Mills, J. (1958). Changes in Moral Attitude Following Temptation. Journal of Personality. https://doi.org/10.1111/j.1467-6494.1958.tb02349.x

[61] Montelbano, J.M. (2017). Split-Level Morality. Inquirer.Net. Retrieved from https://opinion.inquirer.net/100988/split-levelmorality.

[62] Murphy, M. (2019). The Natural Law Tradition in Ethics. Stanford Encyclopedia of Philosophy. Retrieved from https://plato.stanford.edu/entries/natural-law-ethics/

[63] Nohria, N., Sandelands, L., \& Lawrence, P.R. (2006). Driven: Human Nature Shapes Our Choices. Administrative Science Quarterly. Vol. 48, Issue 3.

[64] Ochoa, D.P., Sio, Ch.P., Quinones, D.M. \& Manalastas, D.J. (2016). A Bond Between Man and Woman: Religiosity, Moral Foundations and Same Sex Marriage Attitudes in The Philippines. Philippine Journal of Psychology, 2016, Vol. 49, Issue, 2, pp. 157-171.

[65] O’Neil, K.J. \& Black, P. (2004). The Essential Moral Handbook: A Guide to catholic Living. Bengaluru, India: Asian Trading Corporation.

[66] Ozar, D. T.(1991). The Ethical Ramifications of Cheating.Journal of Dental Education, vol 55 no. 4 pp. 276-81 Apr 1991.

[67] Pecorino, Ph.A. (Ed.) (2017). Academic Integrity and Cheating: Why is it Wrong to Cheat? A Conference Paper Presented at Queensborough Community College, CUNY.

[68] Pew Research Centre (2011). Table: Christian Population as Percentage of Total Population by Country. Retrieved from https://www.pewforum.org/2011/12/19/table-christianpopulation-as-percentages-of-total-population-by-country/

[69] Rappler (2014). "Philippine population officially hits 100 million". Retrieved fromhttps://www.rappler.com/nation/64465100-millionth-filipino-born.

[70] Ratzinger, J. (2005). Introduction to Christianity, 2nd Edition (Communio Books) (Kindle Locations 304-306). Italy: Ignatius Press.

[71] Ridley M. (2011). Nature Via Nurture: Genes, Experience and What Makes Us Human. New York: Harper Perennial.

[72] Rosenberg, M.J. \& Hovland, C.I. (1960). Cognitive, Affective and Behavioral Components of Attitudes. In Hovland, C.I. \& Rosenberg, M.J. (Eds). Attitude Organization and Change, pp. 114. New haven, CT: Yale University Press.

[73] Sanwong, Kh. (2010). Moral Based Thinking Process Skills for Students' Morality and Ethics Development. International Journal of Arts and Sciences, 3(17): 287-297 (2010).

[74] Sharath A. J., Baby J. D., Janani, P., Jessy, Kavya, S. \& Khushbu, S. (2013). Attitudes of Students and Teachers on Cheating Behaviors:
Descriptive Cross-Sectional Study at Six Dental Colleges in India. Journal of Dental Education October 2013, 77 (10) 1379-1383;

[75] Shu, L.L., Gino, F., \& Bazerman, M.H. (2011). Ethical Discrepancy: Changing Our Attitudes to Resolve Moral Dissonance, in Behavioural Business Ethics: Ideas on an Emerging Field. USA: Taylor and Francis Publishing.

[76] Strother, J. (2013). Power of the Catholic Church Slipping in Philippines. The Christian Science Monitor. Retrieved from https://www.csmonitor.com/World/Asia-

Pacific/2013/0306/Power-of-the-Catholic-Church-slipping-inPhilippines.

[77] Thomas, W.I., \& Znaniecki, F. (1918). The Polish Peasant in Europe and America (vol. 1). Boston: Bedger.

[78] Waller, B. N. (2005). Consider Ethics: Theory, Readings, and Contemporary Issues. New York: Pearson Longman: 23.

[79] Watson, J.B. (1925). Behaviorism. New York: Norton.

[80] Wicker, A.W. (1969). Attitudes versus Actions: The relationship of verbal and overt behavioural responses to attitude objects. Journal of Social Issues, 25, 41-78.

[81] Wicker, A. W., \& Pomazal, R. J. (1971). The relationship between attitudes and behaviour as a function of specificity of attitude object and presence of a significant person during assessment conditions. Representative Research in Social Psychology, 2(2), 26-31. 